\title{
Transitivity Shifts in Translating of the Novel Laskar Pelangi into English
}

\author{
Mia Fitri Tinambunan \\ English Applied Linguistic Study Program \\ Postgraduate School \\ Universitas Negeri Medan \\ Medan, Indonesia \\ Email: tinambunanmiafitri@gmail.com
}

\author{
Didik Santoso \\ English Applied Linguistic Study Program \\ Postgraduate School \\ Universitas Negeri Medan \\ Medan, Indonesia
}

\author{
Wayan Dirgayasa Tangkas \\ English Applied Linguistic Study Program \\ Postgraduate School \\ Universitas Negeri Medan \\ Medan, Indonesia
}

\begin{abstract}
-this research was conducted investigated transitivity shift in Laskar Pelangi Novel. The Objective of the researcher was to find out types of transitivity shift used by Laskar Pelangi Novel. The researcher used transitivity of Halliday (1985) and transitivity shift of Calzada Perez (2007) as the tools of analysis. It can be seen that the transitivity shift occured in the speeches. The translators used more active clauses in the target text and use more than one processes in the clauses of the target text. The target texts are more understandable because it is explained clearer. From the findings about transitivity shift, it was found that the transitivity shifts happened in order to adapt the target language so that the translated text can be understood by the target audiences and it should be natural. The analysis shows that material process is dominantly used in the texts of Laskar Pelangi. And also find five transitivity shift like expansion, contraction, materialization, determaterialization and the different of material process. However, almost any decision in translation is consciously or unconsciously guided by translator's background (point of view, ideology or cultural values). In conclusion, the translators tend to leave the reader in peace as much as possible by bringing the text as close as possible to the target text or home to the reader.
\end{abstract} shift

Keywords-Functional Grammar, Transitivity, Translation

\section{INTRODUCTION}

Every year many books of knowledge, science and technology are published. They are released as the replacement or the additional information of the books. They are published in different language not only in English, etc. For example one may talk of translation as a process or a product, identify such sub-types as a literary translation, technical translation, subtitling and machine translation, moreover, while more typically it just refers to the transfer of written texts, the term sometimes also includes interpreting.
In Systemic Function Linguistic, there is theory of Transitivity. Transitivity (Halliday, 1985: 102) is a relation of experiential meaning of a language. It is concerned with the representation of meaning in the clause. It consists of six processes i.e, material, mental, behavioral, verbal, existential, and relational process. Furthermore Processes (Gerot and Wignel, 1994: 54) are central to Transitivity and realized by verbs.

Processes/functions can be subdivided into different types. There are six different process/function that are identified by Halliday (1994: 14):

While Material Process is loosely defined as a 'process of material doing', Mental Process is described as a 'process of thinking or feeling'. In addition, Verbal Process is a process of saying. Between Material and Mental processes is Behavioral Process which is the focus of the present study. According to Halliday, this particular process is a "half-way house" between Material and Mental processes. Eggins (1994:230) elaborates that the meanings Behavioral Process realize are midway between materials on the one hand and mental on the other. They are in part about action, but it is action that has to be physiologically or psychologically experienced by a conscious being. Relational process refers to a process of being and relation among entities through attribution and identification. The verbs categorized as this process are BE (is, am, are, was, were, etc) as in My father is a teacher. Existential process represents something existing or happening. It shares features of relational process in the sense that the common verb is $\mathrm{BE}$ (is, am, are, was, were, etc), and other verbs such as go, come, toil.

The transitivity Shift concerns with the changing process in Source Text (ST) in another process in Target Text (TT). For example:

Waktu masi duduk di bangku sekolah dasar. When she was in grade school. 
From the examples above, there are some possible questions, which might be raised, such as: (1) does the translation of the transitivity denote the same type of transitivity process in the TL? (2) Is there any difference of occurrence in translating transitivity from the SL into TL? (3) Is there any differences in translating transitivity process?. Those questions are one of the reasons why it is interesting and important to analyze the transitivity system in translating Laskar Pelangi Novel

The word $\underline{d u d u k}$ is the material process because it expresses the nation that an entity physical does something which may be done to some other entity. While the word was as existential process because the existential process are expressed by verbs of existing; be, exist, and arise. The existent can be a phenomenon of any kind. It contains the circumstantial element and the word "there" may be omitted.

The source of the data in this thesis is taken novel in Indonesia entitled "Laskar Pelangi" by an Indonesian novelist, Andrea Hirata, with its translation into English entitled "The Rainbow Troops" translated by Angie Kilbane.

The objective of this research is:

1. To describe the types of transitivity are found in translating the novel "Laskar Pelangi" from Indonesia into English

\section{REVIEW OF RELATED LITERATURE}

Halliday in Pardiyono (2007:16) states that transitivity is the meaning of clauses, which represent the pattern of experience. Transitivity system belongs to experiential metafunctions. When we look at the experiential metafunctions, we are looking at the grammar of the clause as representation. It is called so because the clause in its experiential function is a way of representing pattern of experience. Through the system of transitivity, we can explore the clause in its aspects such is:

Who $=$ does $=$ what $=$ to $=$ whom, when, where, why or how function

When people talk about what a word or sentence means, it is kind of meaning they have in mind. Meaning in this sense is related to content or idea. So, here the clause that functions as the representation of processes explores by transitivity system. Transitivity analysis offers a description of one of the structural strands of the clause. Transitivity specifies the different types of process that are recognized in the language, and the structures by which they are expressed.

There are three semantic categories which explain in general way. How phenomena of the real world are represented as linguistic structures. These are :

1. The process it self

2. Participants in the process

3. Circumstance associated with the process

Processes can be subdivided into different types. There are six different process types identified by Halliday:
TABLE 1. DIFFERENT PROCESS TYPES IDENTIFIED

\begin{tabular}{|c|c|c|c|}
\hline 1 & Material & Doing & $\begin{array}{l}\text { bodily, } \\
\text { materially }\end{array}$ \\
\hline & Mental & Sensing & $\begin{array}{l}\text { emotionally, intellectually, } \\
\text { sensorilly }\end{array}$ \\
\hline & Relational & Being & 1 to, or some attribute $\mathrm{o}$ \\
\hline & Verbal & Saying & ally, signaling \\
\hline & Behavioral & Behaving & $\begin{array}{l}\text { ologically and } \\
\text { tologically }\end{array}$ \\
\hline & Existential & existing & there exist \\
\hline
\end{tabular}

Those kinds of processes are realized by verbs. Traditionally, verbs have been defined as "doing words". But, as the above list indicates, it is obvious that some verbs are not doing words at all, but rather express states of being or having the process types differentiate kinds goings-on, for example:

Gina gave some blood (Material)

Gina through she should gave give blood (Mental)

Gina said that giving blood is easy (Verbal)

Gina dreamt of giving blood (Behavioral)

There is a reward for giving blood (Existential)

Gina is a blood donor (Relational)

Process Transitivity shift is made by Calzada Perez (2007) to categorize transitivity in translation into several shifts such as expansion, contraction, materialization, determaterialization and different types of material processes in ST and TT.

\section{RESEARCH METHODOLOGY}

In this research, the researcher tend to use the qualitative method, that is, by using the data stated in written explanation and argument from some books and the previous findings in which the researcher found by doing the library research and it explains the data systematically, factually and accurately.

The data sources of this research were the original novel and the translated novel of "The Rainbow Troops". The original novel is "Laskar Pelangi" written by Adrea Hirata with its translation into English entitled "The Rainbow Troops" translated by Angie Kilbane. Both of the novels were taken from the internet in the form PDF document. The original version, Laskar Pelangi, has 494 pages while the English translated version, "The Rainbow Troops" has 478 pages.

The data were analyzed through three procedures, namely (1) data condensation, (2) data display, and (3) conclusion drawing and verification [5].

\section{IV.RESEARCH FINDINGS AND DISCUSSIONS}

1. We found that the six processes were really used in the texts of Laskar Pelangi Novel. They are Material, Mental, Behavioral, Relational, Verbal, and Existential Processes. 
TABLE 2. PERCENTAGE OF THE PROCESS

\begin{tabular}{|l|l|l|l|}
\hline No. & Process Types & Frequency & Percentage \\
\hline $\mathbf{1}$ & Material Process & 183 & $51.69 \%$ \\
\hline $\mathbf{2}$ & Mental Process & 64 & $18.07 \%$ \\
\hline $\mathbf{3}$ & $\begin{array}{l}\text { Behavioral } \\
\text { Process }\end{array}$ & 10 & $2.84 \%$ \\
\hline $\mathbf{4}$ & $\begin{array}{l}\text { Relational } \\
\text { Process }\end{array}$ & 71 & $20.17 \%$ \\
\hline
\end{tabular}

2. The dominant process of Laskar Pelangi Novel is Material Process. Material process was the dominant process that shows the activity done (physically, bodily, and materially) by people or thing. Material Process is the process that indicates activities or events, which are in the outside human being. A material clause construes doings and happenings including actions, activities, and events. Some verbs belong to material process; cut, run, eat, eat, manage, take, operate, climb, dig, etc.

\section{CONCLUSION}

From the analysis of Transitivity Process in Translating of Novel Laskar Pelangi, the following conclusions can be drawn to complete the findings. Process types of transitivity system namely material process, behavioral process, mental process, verbal process, relational process and existential process, were used. Total occurrence of Material Processes $51.69 \%$, followed by Mental Process is $18.07 \%$, Behavioral Process is $2.84 \%$, Relational Process is $20.17 \%$, Verbal Process is 4.51 $\%$, and Existential Process is $3.27 \%$. From the result above, the most dominant process used in texts of Laskar Pelangi Novel is Material Process. Material process was dominantly used because most of the texts show the activity done (physically, bodily, and materially) by people or thing. A material clause construes doings and happenings including actions, activities, and events.

\section{REFERENCES}

[1] Calzada Perez, M. (2007). Transitivity in translating: The interdepence of texture and context. Peter Lang

[2] Catford, J. C. 1965. A Linguistic Theory of Translation. London: Oxford University Pres

[3] Eggnis, Suzanne . 1994. An Introduction to Systemic Functional Linguistics. London: Pinter Publisher.

[4] Halliday, M.A.K 1994. An Introduction to Functional Grammar: second Edition. London: Edward Arnold.

[5] Ghazanfari, M \& Sarani, A.(2009). The manifestation of ideology in literary translation

[6] Lubis, Suraidah. 2007. An Analysis of Grammatical Unit Shift in The Translation of Agatha Christie's

[7] Sinar, T. Silvana . 2002. An Introduction to a Systemic- Functional Oriented Discourse Analysis. Singapore: Deezed Consult (published) 